\title{
KEBIJAKAN STANDAR NASIONAL PENDIDIKAN
}

\author{
Oleh: \\ Miftahul Ulum ${ }^{1}$ \\ Email: miftahul_ulum2001@yahoo.com
}

\begin{abstract}
National Education Standards are minimum criteria regarding the education system in the entire jurisdiction of the Unitary Republic of Indonesia. The policy regarding National Education Standards is contained in Government regulation No. 19 of 2005 This regulation is a translation of Law No. 20 of 2003 concerning the National Education System. And along with the enactment of the 2013 curriculum, the policy changed to Government Regulation No. 32 of 2013 concerning Amendments to Government Regulation No. 19 of 2005 concerning National Education Standards. National Education Standards contain 8 minimum criteria which include: graduate competency standards, content standards, process standards, teacher and education staff standards, facilities and infrastructure standards, management standards, financing standards, education assessment standards.
\end{abstract}

Keywords: policy, education, national education standards.

\section{Pendahuluan}

Seperti kita ketahui, dan masyarakat luas menyadari, bahwa mutu pendidikan nasional sudah tercecer dari bangsa-bangsa lain termasuk negara-negara tetangga kita. Berawal dari situlah timbul hasrat yang besar untuk memperbaiki dan dan meningkatkan mutu pendidikan nasional. ${ }^{2}$

Dengan dalih untuk meningkatkan mutu dan standar pendidikan nasional maka diadakanlah berbagai usaha dan peraturan untuk menyeragamkan pendidikan nasional. Dari sinilah kita mulai mengenal norma-norma nasional yang dicapai melalui ujian nasional. Berbagai cara dilaksanakan untuk mencapai mutu pendidikan yang dicita-citakan seperti dikembangkannya tes-tes standar untuk menyeragamkan mutu pendidikan di seluruh negara. Meski dari segi tertentu menunjukkan hasil

${ }^{1}$ Dosen STAI Syaichona Moh. Cholil Bangkalan

${ }^{2}$ H.A.R. Tilaar, Standarisasi Pendidikan Nasional: Suatu Tinjauan Kritis (Jakarta: Rineka Cipta, 2012), 105. 
yang menggembirakan seperti percepatan pencapaian target-target kuantitatif pendidikan. Namun, banyak pula hasil negatif yang dilahirkan di dari sistem pendidikan yang diatur oleh keinginan pencapaian keseragaman nasional. ${ }^{3}$

Selama ini kita lihat betapa pendidikan telah diredusir sebagai proses untuk lulus ujian nasional tetapi tidak diarahkan untuk membentuk masyarakat yang bermoral dan beradab. Pendidikan kita selama ini mulai dari proses, metodologi, sistem, telah menghasilkan manusia-manusia robot dan hanya menerima petunjuk dan pengarahan dari atas. Oleh karena itu, masyarakat bukannya menjadi berdaya tapi diperdayakan oleh sistem yang otoriter. ${ }^{4}$

\section{Teori Kebijakan Standar Nasional Pendidikan}

Menurut Fred N. Kerlinger sebagaimana yang dikutip oleh Nanang Fattah, teori adalah seperangkat konsep, asumsi, dan generalisasi yang saling berhubungan yang secara sistematis menggambarkan dan menjelaskan keteraturan perilaku dalam organisasi pendidikan. ${ }^{5}$

Menurut kamus Oxford, kebijakan berarti rencana kegiatan atau pernyataan tujuan-tujuan ideal. ${ }^{6}$ Istilah kebijakan (policy) seringkali dicampur-adukkan dengan kebijaksanaan (wisdom). Namun, sebenarnya kedua istilah tersebut memiliki makna yang berbeda. Landasan utama yang mendasari suatu kebijakan adalah pertimbangan akal, sedangkan kebijaksanaan lebih menekankan kepada faktor-faktor emosional dan irrasional.7 Adapun kebijakan pendidikan berkenaan dengan pengaturan

${ }^{3}$ H.A.R. Tilaar, Paradigma Baru Pendidikan Nasional (Jakarta: Rineka Cipta, 2010), 66.

${ }^{4}$ Ibid., 21.

5 Nanang Fattah, Analisis Kebijakan Pendidikan (Bandung: PT. Remaja Rosdakarya, 2013), 37.

${ }^{6}$ Ibid., 131.

7 H.A.R. Tilaar \& Riant Nugroho, Kebijakan Pendidikan: Pengantar untuk memahami kebijakan pendidikan dan kebijakan pendidikan sebagai kebijakan publik (Yogyakarta: Pustaka Pelajar, 2012), 16. 
kehidupan dengan sesama manusia. Hal ini menunjukkan aspek sosialitas dari keberadaan manusia. ${ }^{8}$

Menurut Yoyon Bahtiar Irianto, kebijakan merupakan segala perbuatan yang dikehendaki pemerintah untuk dilakukan atau tidak dilakukan yang dirumuskan dalam suatu kebijakan, untuk mencapai tujuan yang hendak dicapai melalui program-program pemerintah. ${ }^{9}$

Kebijakan mengenai Standar Nasional Pendidikan tertuang dalam peraturan Pemerintah No. 19 athun 2005 Peraturan ini merupakan penjabaran dari UU No. 20 tahun 2003 tentang Sistem Pendidikan Nasional. Dan seiring dengan pemberlakuan kurikulum 2013, kebijakan tersebut berubah menjadi Peraturan Pemerintah No. 32 tahun 2013 tentang Perubahan atas Peraturan Pemerintah No. 19 Tahun 2005 tentang Standar Nasional Pendidikan.

Dalam Peraturan Pemerintah Bab I ayat 1 disebutkan bahwa Standar Nasional Pendidikan adalah kriteria minimal tentang sistem pendidikan di seluruh wilayah hukum Negara Kesatuan Republik Indonesia. ${ }^{10}$ Standar Nasional Pendidikan berfungsi sebagai dasar dalam perencanaan, pelaksanaan, dan pengawasan pendidikan dalam rangka mewujudkan pendidikan nasional yang bermutu. Sesuai dengan fungsinya, Standar Nasional Pendidikan bertujuan menjamin mutu pendidikan nasional dalam rangka mencerdaskan kehidupan bangsa dan membentuk watak serta peradaban bangsa yang bermartabat. Dalam hal ini Standar Nasional Pendidikan disempurnakan secara terencana, terarah, dan berkelanjutan sesuai dengan tuntutan perubahan kehidupan lokal, nasional, dan global. ${ }^{11}$

Untuk mendukung tercapainya Standar Nasional Pendidikan dibentuk sebuah badan yang disebut Badan Standar Nasional Pendidikan yang disingkat BNSP, yaitu sebuah badan mandiri dan independen yang

${ }^{8}$ Ibid., 18.

${ }^{9}$ Yoyon Bahtiar Irianto, Kebijakan Pembaruan Pendidikan: Konsep, Teori, dan Model (Jakarta: Rajawali Pers, 2011), 34.

${ }^{10}$ Susilo Bambang Yudhoyono, Peraturan Pemerintah No.19 tahun 2005 tentang Standar Nasional Pendidikan, (Jakarta: Presiden Republik Indonesia, 2005), 2.

${ }^{11} \mathrm{https}$ ://id.wikipedia.org/wiki/Standar_Nasional_Pendidikan. Diakses hari Jum'at 6 Maret 2020. 
bertugas mengembangkan, mengatur pelaksanaan, dan mengevaluasi Standar Nasional Pendidikan. ${ }^{12}$

\section{Lingkup SNP dan Kriterianya}

Menurut Dr. H. Moh. Kosim, M. Ag, dalam rangka menjamin mutu pendidikan, penyelenggaraan pendidikan nasional harus berpedoman pada pada kriteria minimal SNP yang berlaku di seluruh wilayah hukum Negara Kesatuan Republik Indonesia. Kriteria minimal tersebut telah ditetapkan pemerintah melalui Peraturan Pemerintah No. 19 tahun 2005 tentang Standar Nasional Pendidikan, meliputi: ${ }^{13}$

1. Standar kompetensi lulusan, yaitu kualifikasi kemampuan lulusan yang mencakup sikap, pengetahuan, dan keterampilan. Kebijakan standar kompetensi lulusan ini tertuang dalam peraturan menteri pendidikan nasional No. 23 tahun 2006 tentang Standar Kompetensi Lulusan untuk Satuan Pendidikan Dasar dan Menengah.

Penjabaran dari Permendiknas tersebut tertuang dalam lampiran peraturan menteri pendidikan nasional No. 23 tahun 2006 tanggal 23 Mei 2006, yang menyatakan bahwa Standar Kompetensi Lulusan Satuan Pendidikan (SKL-SP), meliputi:
a. SD/MI/SDLB/Paket A
b. SMP/MTs./SMPLB/Paket B
c. SMA/MA//SMALB/Paket C
d. SMK/MAK

Standar kompetensi lulusan satuan pendidikan (SKL-SP) dikembangkan berdasarkan tujuan setiap satuan pendidikan, yakni:

a. Pendidikan dasar, yang meliputi SD/MI/SDLB/Paket A dan SMP/MTs./SMPLB/Paket B bertujuan: meletakkan dasar kecerdasan, pengetahuan, kepribadian, akhlak mulia, serta keterampilan untuk hidup mandiri dan mengikuti pendidikan lebih lanjut.

12 M. Sukardjo \& Ukim Komarudin, Landasan Pendidikan: Konsep dan Aplikasinya (Jakarta: Rajawali Pers, 2012), 85.

${ }_{13}$ Mohammad Kosim, Pengantar Ilmu Pendidikan (Surabaya: Pena Salsabila, 2013), 128-130. 
b. Pendidikan menengah yang terdiri atas SMA/MA/SMALB/Paket C, bertujuan: meningkatkan kecerdasan, pengetahuan, kepribadian, akhlak mulia, serta keterampilan untuk hidup mandiri dan mengikuti pendidikan lebih lanjut.

c. Pendidikan menengah kejuruan yang terdiri atas SMK/MAK, bertujuan: meningkatkan kecerdasan, pengetahuan, kepribadian, akhlak mulia, serta keterampilan untuk hidup mandiri dan mengikuti pendidikan lebih lanjut sesuai dengan kejuruannya. ${ }^{14}$

2. Standar isi, yaitu ruang lingkup materi dan tingkat kompetensi tamatan, kompetensi bahan kajian, kompetemsi mata pelajaran, dan silabus pembelajaran yang harus dipenuhi oleh peseta didik pada jenjang dan jenis pendidikan tertentu.

Kebijakan tentang standar isi ini tertuang dalam Peraturan Pemerintah No. 19 tahun 2005 tentang Standar Nasional Pendidikan pada Bab III pasal 5 ayat (1) dan (2), dengan rincian sebagai berikut: Pasal 5

(1) Standar isi mencakup lingkup materi dan tingkat kompetensi untuk mencapai kompetensi lulusan pada jenjang dan jenis pendidikan tertentu

(2) Standar isi sebagaimana dimaksud pada ayat (1) memuat kerangka dasar dan struktur kurikulum, beban belajar, kurikulum tingkat satuan pendidikan, dan kalender pendidikan/akademik.15

3. Standar proses, yaitu standar nasional pendidikan yang berkaitan dengan pelaksanaan pembelajaran pada satuan pendidikan untuk mencapai standar kompetensi lulusan.

Dalam peraturan pemerintah No. 19 tahun 2005 pasal 19 ayat 1 dinyatakan bahwa proses pembelajaran pada satuan pendidikan diselengggarakan secara interaktif, inspiratif, menyenangkan,

${ }^{14}$ Lampiran peraturan menteri pendidikan nasional No. 23 tahun 2006 tanggal 23 Mei 2006 tentang Standar Kompetensi Lulusan (SKL), 342.

${ }^{15}$ Susilo Bambang Yudhoyono, Peraturan Pemerintah No.19 tahun 2005 tentang Standar Nasional Pendidikan: Bab IV Standar Proses (Jakarta: Presiden Republik Indonesia, 2005), 7. 
menantang, memotivasi peserta didik yang utuk berpartisipasi aktif, serta memberikan ruang yang cukup bagi prakarsa, kreativitas, dan kemandirian sesuai dengan bakat, minat, dan perkembangan fisik serta psikologis peserta didik. Selanjutnya dipertegas dalam pasal 20 bahwa seorang guru merencanakan proses pembelajaran meliputi tujuan pembelajaran, materi ajar, metode pembelajaran, sumber belejara dan penilaian hasil belajar. ${ }^{16}$

4. Standar pendidik dan tenaga kependidikan, adalah kriteria pendidikan pra jabatan dan kelayakan fisik maupun mental, serta pendidikan dalam jabatan.

Peraturan pemerintah No. 19 tahun 2005 pasal 28 ayat 1 menggaris bawahi bahwa pendidik harus memiliki kualifikasi akademik dan kompetensi sebagai agen pembelajaran, sehat jasmani dan rohani serta memiliki kemampuan untuk mewujudkan pendidikan nasional.

Peran guru sebagai agen pembelajaran disebutkan dalam pasal 28 ayat 3 yang menyebutkan bahwa guru sebagai agen pembelajaran pada jenjang pendidikan dasar dan menengah serta pendidikan anak usia dini harus memiliki beberapa kompetensi, meliputi: kompetensi pedagogik, kompetensi kepribadian, kompetensi profesional, dan kompetensi sosial. ${ }^{17}$

5. Standar sarana dan prasarana, adalah standar nasional pendidikan yang berkaitan dengan kriteria minimal tentang ruang belajar, tempat berolahraga, tempat beribadah, perpustakaan, laboratorium, bengkel kerja, tempat bermain, tempat berkreasi dan berekspresi, serta sumber belajar yang lain yang diperlukan untuk menunjang proses pembelajaran, termasuk penggunaan teknologi informasi dan komunikasi.

Kualitas suatu sekolah sangat ditunjang oleh sarana dan prasarana. Dalam hal ini pemerintah menetapkan aturan melalui peraturan pemerintah No. 19 tahun 2005 khususnya padda bab VII pasal 42 ayat 1 yang menegaskan bahwa Setiap satuan pendidikan wajib

${ }^{16}$ Ibid., 17.

${ }^{17}$ Saiful Arif, Etika Profesi Guru (Surabaya: Pena Salsabila, 2014), 52. 
memiliki sarana yang meliputi perabot, peralatan pendidikan, media pendidikan, buku dan sumber belajar lainnya, bahan habis pakai, serta perlengkapan lain yang diperlukan untuk menunjang proses pembelajaran yang teratur dan berkelanjutan.

Selanjutnya dalam pasal 2 juga disebutkan bahwa setiap satuan pendidikan wajib memiliki prasarana yang meliputi lahan, ruang kelas, ruang pimpinan satuan pendidikan, ruang pendidik, ruang tata usaha, ruang perpustakaan, ruang laboratorium, ruang bengkel kerja, ruang unit produksi, ruang kantin, instalasi daya dan jasa, tempat berolahraga, tempat beribadah, tempat bermain, tempat berkreasi, dan ruang atau tempat lain yang diperlukan untuk menunjang proses pembelajaran yang teratur dan berkelanjutan. ${ }^{18}$

6. Standar pengelolaan, adalah standar nasional pendidikan yang berkaitan dengan perencanaan, pelaksanaan, dan pengawasan kegiatan pendidikan pada tingkat satuan pendidikan, kabupaten/kota, provinsi, atau nasional agar tercapai efisiensi dan efektivitas penyelenggaraan pendidikan.

7. Standar pembiayaan, adalah standar yang mengatur komponen dan besarnya biaya operasi satuan pendidikan yang berlaku selama satu tahun.

Pembiayaan pendidikan ${ }^{19}$ sebagaimana yang disebutkan dalam peraturan pemerintah No. 19 tahun 2005, khususnya pada bab IX pasal 62 terdiri atas:

a. Biaya investasi satuan pendidikan meliputi biaya penyediaan sarana dan prasarana, pengembangan sumberdaya manusia, dan modal kerja tetap (ayat 2)

b. Biaya personal sebagaimana dimaksud pada di atas meliputi biaya pendidikan yang harus dikeluarkan oleh peserta didik untuk bisa mengikuti proses pembelajaran secara teratur dan berkelanjutan (ayat 3)

${ }^{18}$ Ibid., 54-55.

19 Penggalian dana pendidikan dapat dilakukan melalui sumber tetap dari pemerintah dan dari masyarakat, atau melalui hasil usaha. Lihat Atiqullah, Manajemen \& Kepemimpinan Pendidikan Islam (Surabaya: Pena Salsabila, 2012), 62 
c. Biaya operasi satuan pendidikan meliputi: Gaji pendidik dan tenaga kependidikan serta segala tunjangan yang melekat pada gaji, Bahan atau peralatan pendidikan habis pakai, dan Biaya operasi pendidikan tak langsung berupa daya, air, jasa telekomunikasi, pemeliharaan sarana dan prasarana, uang lembur, transportasi, konsumsi, pajak, asuransi, dan lain sebagainya (ayat 4 ). ${ }^{20}$

8. Standar penilaian pendidikan, adalah standar nasional pendidikan yang berkaitan dengan mekanisme, prosedur, dan instrumen penilaian hasil belajar peserta didik.

Standar penilaian pendidikan terdapat dalam peraturan pemerintah No. 19 tahun 2005, khususnya pada Bab X pasal 63 yang dirinci dalam masing-masing ayatnya sebagai berikut:

(1) Penilaian pendidikan pada jenjang pendidikan dasar dan menengah terdiri atas:

a. Penilaian hasil belajar oleh pendidik;

b. Penilaian hasil belajar oleh satuan pendidikan; dan

c. Penilaian hasil belajar oleh Pemerintah.

(2) Penilaian pendidikan pada jenjang pendidikan tinggi terdiri atas:

a. Penilaian hasil belajar oleh pendidik; dan

b. Penilaian hasil belajar oleh satuan pendidikan tinggi.

(3) Penilaian pendidikan pada jenjang pendidikan tinggi sebagaimana dimaksud pada ayat (2) diatur oleh masing-masing perguruan tinggi sesuai peraturan perundang-undangan yang berlaku. ${ }^{21}$

\section{Problema Implementasi Standar Nasional Pendidikan}

Terkait dengan upaya peningkatan mutu pendidikan melalui penyeragaman pendidikan nasional yang diwujudkan dalam penetapan SNP, terdapat beberapa kendala yang menghambat ketercapaian tujuan tersebut. Adapun problem atau kendalanya akan di urai pada tabel di bawah ini.

${ }^{20}$ Susilo Bambang Yudhoyono, Peraturan Pemerintah No.19 tahun 2005 tentang Standar Nasional Pendidikan: Bab IX Standar Pembiayaan (Jakarta: Presiden Republik Indonesia, 2005), 44-45.

${ }^{21}$ Ibid., 45. 


\begin{tabular}{|c|c|}
\hline Komponen Standar & Problem/kendala implementasi SNP \\
\hline $\begin{array}{ll}\text { Standar } & \text { kompetensi } \\
\text { lulusan } & \end{array}$ & $\begin{array}{l}\text { - Ujian nasional yang digunakan untuk } \\
\text { mengukur kompetensi lulusan tidak bisa } \\
\text { dijadikan tolok ukur karena mekanisme } \\
\text { pembelajaran banyak yang belum memenuhi } \\
\text { standar. } \\
\text { - Alokasi waktu pembelajaran kurang, masing- } \\
\text { masing sekolah berbeda } \\
\text { - Input siswa yang berbeda dengan kualitas yang } \\
\text { berbeda antara sekolah di perkotaan dan } \\
\text { pedesaan. }\end{array}$ \\
\hline Standar isi & $\begin{array}{l}\text { - Penggunaan dua kurikulum yakni KTSP dan } \\
\text { K-13 sering kali menimbulkan dilema di } \\
\text { kalangan para guru dalam penyampaian materi } \\
\text { pembelajaran. } \\
\text { - Ketersediaan buku K-13 yang terbatas } \\
\text { - Kurangnya kesiapan dan pemahaman tentang } \\
\text { kurikulum 13, baik guru maupun siswa }\end{array}$ \\
\hline Standar proses & $\begin{array}{l}\text { - Guru kurang memperhatikan perbedaan } \\
\text { kemampuan siswa dalam penentuan metode } \\
\text { pembelajaran } \\
\text { - Kurangnya guru memahami proses dan model- } \\
\text { model pembelajaran inovatif dalam Kurikulum } \\
\text { 2013. }\end{array}$ \\
\hline $\begin{array}{l}\text { Standar pendidik dan } \\
\text { tenaga kependidikan }\end{array}$ & $\begin{array}{l}\text { - Banyak guru yang mengajar tidak sesuai } \\
\text { dengan latar belakang pendidikannya. } \\
\text { - Kompetensi professional dan pedagogi yang } \\
\text { masih rendah }\end{array}$ \\
\hline $\begin{array}{lll}\text { Standar } & \text { sarana } & \text { dan } \\
\text { prasarana } & & \end{array}$ & $\begin{array}{l}\text { - Minimnya asupan dana membuat sekolah } \\
\text { kesulitan dalam penyediaan sarana dan } \\
\text { prasarana sebagaimana yang sudah yang sudah } \\
\text { ditetapkan }\end{array}$ \\
\hline
\end{tabular}




\begin{tabular}{|c|c|}
\hline Standar pengelolaan & $\begin{array}{l}\text { - Kurangnya sosialisasi dengan masyarakat, } \\
\text { khususnya wali murid dalam perencaaan } \\
\text { program-program pembelajaran } \\
\text { - Pengelolaan belum dilakukan secara } \\
\text { professional }\end{array}$ \\
\hline Standar pembiayaan & $\begin{array}{l}\text { - Sumber dana utama hanya dari BOS yang } \\
\text { pencairannya pun juga seringkali tersendat- } \\
\text { sendat. } \\
\text { - Operasional sekolah belum mencukupi untuk } \\
\text { memenuhi standar nasional pendidikan }\end{array}$ \\
\hline $\begin{array}{l}\text { Standar } \\
\text { pendidikan }\end{array}$ & $\begin{array}{l}\text { - Laporan penilaian akhir semester tidak murni, } \\
\text { banyak yang dikatrol karena banyak siswa } \\
\text { yang tidak bisa mencapai KKM. } \\
\text { - Penilaian belum dilakukan secara } \\
\text { komprehensif }\end{array}$ \\
\hline
\end{tabular}

\section{Penutup}

Kebijakan merupakan segala perbuatan yang dikehendaki pemerintah untuk mencapai tujuan yang hendak dicapai melalui program-program pemerintah. Dalam rangka menjamin mutu pendidikan, pemerintah menyelenggarakan pendidikan nasional melalui penetapan Standar Nasional Pendidikan.

Standar Nasional Pendidikan adalah kriteria minimal tentang sistem pendidikan di seluruh wilayah hukum Negara Kesatuan Republik Indonesia. Standar Nasional Pendidikan berfungsi sebagai dasar dalam perencanaan, pelaksanaan, dan pengawasan pendidikan dalam rangka mewujudkan pendidikan nasional yang bermutu.

Kebijakan mengenai Standar Nasional Pendidikan tertuang dalam peraturan Pemerintah No. 19 athun 2005 Peraturan ini merupakan penjabaran dari UU No. 20 tahun 2003 tentang Sistem Pendidikan Nasional. Dan seiring dengan pemberlakuan kurikulum 2013, kebijakan tersebut berubah menjadi Peraturan Pemerintah No. 32 tahun 2013 tentang Perubahan atas Peraturan Pemerintah No. 19 Tahun 2005 tentang Standar Nasional Pendidikan. 
Standar Nasional Pendidikan memuat 8 kriteria minimal yang meliputi: standar kompetensi lulusan, standar isi, standar proses, standar pendidik dan tenaga kependidikan, standar sarana dan prasarana, standar pengelolaan, standar pembiayaan, standar penilaian pendidikan.

\section{DAFTAR PUSTAKA}

Arif, Saiful. 2014. Etika Profesi Guru. Surabaya: Pena Salsabila.

Atiqullah. 2012. Manajemen \& Kepemimpinan Pendidikan Islam. Surabaya: Pena Salsabila.

Fattah, Nanang. 2013. Analisis Kebijakan Pendidikan. Bandung: PT. Remaja Rosdakarya.

Tilaar, H.A.R. 2010. Paradigma Baru Pendidikan Nasional. Jakarta: Rineka Cipta.

Tilaar, H.A.R..2012. Standarisasi Pendidikan Nasional: Suatu Tinjauan Kritis. Jakarta: Rineka Cipta.

Tilaar, H.A.R. \& Riant Nugroho. 2012. Kebijakan Pendidikan: Pengantar untuk memahami kebijakan pendidikan dan kebijakan pendidikan sebagai kebijakan publik. Yogyakarta: Pustaka Pelajar.

https://id.wikipedia.org/wiki/Standar_Nasional_Pendidikan. Diakses hari Jum'at 6 Maret 2020.

Irianto, Yoyon Bahtiar. 2011. Kebijakan Pembaruan Pendidikan: Konsep, Teori, dan Model. Jakarta: Rajawali Pers.

Kosim, Mohammad. 2013. Pengantar Ilmu Pendidikan. Surabaya: Pena Salsabila.

Lampiran Peraturan Menteri Pendidikan Nasional No. 23 tahun 2006 tanggal 23 Mei 2006 tentang Kompetensi Lulusan (SKL). 
Sukardjo, M. \& Ukim Komarudin. 2012. Landasan Pendidikan: Konsep dan Aplikasinya. Jakarta: Rajawali Pers.

Yudhoyono, Susilo Bambang. 2005. Peraturan Pemerintah No.19 tahun 2005 tentang Standar Nasional Pendidikan. Jakarta: Presiden Republik Indonesia. 